Cornell Law Library

Scholarship@Cornell Law: A Digital Repository

Cornell Law Faculty Publications

Faculty Scholarship

$3-2010$

\title{
Why ADR Programs Aren't More Appealing: An Empirical Perspective
}

Michael Heise

Cornell Law School, michael.heise@cornell.edu

Follow this and additional works at: http://scholarship.law.cornell.edu/facpub

Part of the Dispute Resolution and Arbitration Commons, Law and Economics Commons, and the Litigation Commons

\section{Recommended Citation}

Heise, Michael, "Why ADR Programs Aren't More Appealing: An Empirical Perspective" (2010). Cornell Law Faculty Publications. Paper 920.

http://scholarship.law.cornell.edu/facpub/920

This Article is brought to you for free and open access by the Faculty Scholarship at Scholarship@Cornell Law: A Digital Repository. It has been accepted for inclusion in Cornell Law Faculty Publications by an authorized administrator of Scholarship@Cornell Law: A Digital Repository. For more information, please contact jmp8@cornell.edu. 


\title{
Why ADR Programs Aren't More Appealing: An Empirical Perspective
}

\author{
Michael Heise*
}

\begin{abstract}
Standard law and economic theory suggests that litigating parties seeking to maximize welfare will participate in alternative dispute resolution (ADR) programs if they generate a surplus. ADR programs claim to generate social surplus partly through promoting settlements and reducing case disposition time. Although most associate ADR programs with trial courts, a relatively recent trend involves appellate court use of ADR programs. The emergence of court-annexed ADR programs raises a question. Specifically, if ADR programs achieve their goals of promoting settlements and reducing disposition time, why do some courts find it necessary to impose ADR participation? Attention to ADR's ability to achieve its goals provides one clue. Most empirical assessments of ADR program efficacy have been mixed. This study exploits a uniquely comprehensive database of state civil court trials and appeals and tests hypotheses germane to questions about whether court-annexed appellate ADR programs stimulate settlement and reduce disposition time. Using data from 46 large counties consisting of 8,038 trials that generated 965 filed appeals, with 166 appeals participating in ADR programs, findings from this study provide mixed support for ADR programs. Specifically, results from this study indicate that participation in an ADR program correlates with an increased likelihood of settlement but not with reduced disposition time. ADR program mixed efficacy diminishes its appeal to litigants. Institutional interests help explain why appellate courts impose ADR participation notwithstanding mixed results on ADR efficacy.
\end{abstract}

\section{INTRODUCTION}

Momentum and demand for alternative mechanisms to resolve legal disputes build as dissatisfaction with formal litigation grows. Standard law and economic theory suggests that litigating parties seeking to maximize welfare will participate in alternative dispute resolution (ADR) programs if they generate a surplus. ${ }^{1}$ Although ADR means different things to different people and the scholarly literature notes an array of policies and practices

\footnotetext{
*Professor, Cornell Law School, Myron Taylor Hall, Ithaca, NY 14853.

I am grateful to Dawn M. Chutkow, Theodore Eisenberg, Nicole Heise, Marty Wells, and an anonymous referee for their comments on an earlier version of this article. An earlier version of this article was presented at Northwestern University School of Law's Research Symposium on Empirical Studies of Civil Liability as well as at faculty workshops at Notre Dame Law School and Suffolk University Law School.
}

${ }^{1}$ Steven Shavell, Alternative Dispute Resolution: An Economic Analysis, 24 J. Legal Stud. 1, 5 (1995) (arguing that litigating parties "would tend to adopt ADR if it would lead to mutual advantages"). 
commonly associated with ADR programs, these programs share a claim to generate social surplus partly through promoting settlements and reducing case disposition time. ${ }^{2}$ A relatively recent development in the ADR movement is its expansion into appellate litigation. ${ }^{3}$ Responding to increased momentum and demand, alternative dispute resolution (ADR) programs increase in number and influence. ${ }^{4}$ This growth is far from smooth, however, as satisfaction with ADR is uneven. ${ }^{5}$ Uneven satisfaction levels aside, the growing popularity of ADR programs, and their recent expansion into the appellate setting, imply some level of success in achieving their core objectives.

Support for ADR programs is intuitive and those demanding ADR programs range from private litigants to lawmakers and courts. ${ }^{6}$ One distinct subspecies of the broader ADR movement includes court-annexed (or court-mandated) ADR programs. ${ }^{7}$ These mandatory yet nonbinding ADR programs exist in many states for certain types of civil litigation and contribute to the steady increase in ADR programs. ${ }^{8}$ The emergence of court-annexed ADR programs implies, however, that not all litigants perceive ADR programs' benefits. If they did, court-annexed ADR programs would be redundant as a policy option. Why do courts feel the need to compel ADR if economically rational litigants would seek such programs? Presumably, courts that impose ADR participation on litigants perceive that benefits from ADR participation must exist independent of litigants' perspectives. Consequently, attention to courts' institutional interests is warranted.

It is important to keep in mind how ADR programs seek to achieve their twin goals of increased settlements and reduced case disposition time. Most critically, ADR programs

\footnotetext{
${ }^{2}$ See, e.g., Wayne D. Brazil, Should Court-Sponsored ADR Survive? 21 Ohio St. J. on Disp. Resol. 214,247 (2006) (noting that the most "common promise" was that ADR programs would reduce cost and delay in civil litigation); James F. Henry, The Courts at a Crossroads: A Consumer Perspective of the Judicial System, 95 Geo. L. J. 945 (2007) (addressing arguments for ADR in the federal context); Thomas J. Stipanowich, ADR and the "Vanishing Trial": The Growth and Impact of "Alternative Dispute Resolution," 1 J. Empirical Legal Stud. 843, 875 (2004) ("The Search for Less Costly, More Timely Resolution”).
}

${ }_{3}^{3}$ Jeremy L. Fetty, Pre-Argument Settlement at the Michigan Court of Appeals: A Secret Too Well Kept, 7 J. App. Prac. \& Process 317, 317 (2005) (noting that appellate ADR programs emerged in the late 1980s and early 1990s).

${ }^{4}$ For a recent summary, see, e.g., Donna Shestowsky \& Jeanne M. Brett, Disputants' Perceptions of Dispute Resolution Procedures: A Longitudinal Empirical Study (UC Davis Legal Studies Research Paper Series, No. 130, Mar. 2008), at 4 ("Now, more than ever, disputants have a variety of options for resolving legal conflict"). See generally Stipanowich, supra note 2 .

\footnotetext{
${ }^{5}$ For example, for a debate about whether companies increasing eschew arbitration agreements, compare Theodore Eisenberg \& Geoffrey P. Miller, The Flight from Arbitration: An Empirical Study of Ex Ante Arbitration Clauses in the Contracts of Publicly Held Companies, 56 DePaul L. Rev. 335 (2007) (arguing that companies avoid arbitration), with Christopher R. Drahozal \& Quentin R. Wittrock, "Is There a Flight from Arbitration?” available at 〈http://ssrn.com/ abstract=1147697 $\rangle$ (arguing that evidence about a flight from arbitration agreements is inconclusive).
}

${ }^{6}$ See, e.g., Harry T. Edwards, Alternative Dispute Resolution: Panacea or Anathema? 99 Harv. L. Rev. 668, 668 (1986).

${ }^{7}$ For a discussion of court-mandated and court-annexed ADR programs and the particular problems that arise in this context, see generally Brazil, supra note 2 .

${ }^{8}$ More specifically, court-annexed ADR programs exist in 38 of the 46 counties included in the data set. For a fuller description, see Section II. 
seek to stimulate information sharing about a legal dispute among litigants. Additional information provides litigants greater clarity on the likely legal outcome of their dispute. Greater information flow is critical as it facilitates litigants' assessments of the relative and absolute strengths of their legal disputes. With greater legal or factual clarity comes an increased likelihood of settlement. Settlements typically reduce case disposition time and, in so doing, decrease costs (private and public). ${ }^{9}$ Moreover, by identifying the specific contested issues with greater clarity to the parties, a strong form of the ADR argument is that participation generates a net reduction in disposition time even for cases that do not settle and, instead, proceed to trial. ${ }^{10}$

Even where settlement might be less costly and take less time than litigation and where ADR participation might make sense in the abstract, some litigants, perhaps those wary of "second-class justice," 11 either avoid ADR altogether or, after participating in ADR, take legal disputes to trial. Although litigant motives vary across cases, litigants that pursue claims to trial do so partly because they can endure the costs of litigation and, presumably, because they sense some reasonable level of uncertainty-factual or legal-about their case's outcome. ${ }^{12}$ The subpool of disputes that withstands settlement or withdrawal, as well as the various motions for directed verdicts and summary judgments and other dispositions, more likely comprises disputes whose underlying merits reside somewhere in the "gray middle area." Additional-if similar-filters arise during the posttrial appellate process. ${ }^{13}$

Although most associate ADR programs with trial courts, a relatively recent trend involves appellate court use of ADR. The trial and appellate court contexts differ in important structural ways that plausibly influence the efficacy of court-annexed ADR programs. At the pretrial stage, ADR programs offer adverse parties a neutral and realistic forum to better assess what could transpire if their dispute were to proceed to a full, formal

${ }^{9}$ See Brazil, supra note 2, at 247 (identifying relief of court docket pressure as one important public benefit from ADR).

\footnotetext{
${ }^{10}$ See, e.g., Kimberly M. Ruch-Alegant, Note, Markman: In the Light of De Novo Review, Parties to Patent Infringement Litigation Should Consider the ADR Option, 16 Temple Envtl. L. \& Tech. J. 307, 308 (1998) (arguing that even where ADR programs failed to eliminate the need for a trial it could be used to facilitate the construction of the claim issues in a patent dispute). This strong form of the ADR proponent claim, however, does not benefit from empirical support. See Michael Heise, Justice Delayed?: An Empirical Analysis of Civil Case Disposition Time, 50 Case W. Res. L. Rev. 813, 846-47 (2000).
}

${ }^{11}$ For a discussion, see Brazil, supra note 2, at 253-54 (reviewing the "second-class justice" argument).

${ }^{12}$ See generally George L. Priest \& Benjamin Klein, The Selection of Disputes for Litigation, 13 J. Legal Stud. 1 (1984).

${ }^{13}$ Id. at 29 (arguing that, aside from possible precedential concerns, selection effect applies "indistinguishably to trial and appellate disputes"). See also Theodore Eisenberg \& Michael Heise, Plaintiphobia in State Courts? An Empirical Study of State Court Trials on Appeal, 38 J. Legal Stud. (forthcoming 2009); Richard L. Revesz, Litigation and Settlement in the Federal Appellate Courts: Impact of Panel Selection Procedures on Ideologically Divided Courts, 29 J. Legal Stud. 685, 707-08 (2000) (considers the salience of the Priest-Klein prediction of a 50 percent win rate in the federal appellate courts). 
trial. ${ }^{14}$ At the appellate stage, however, both parties already know what happened at trial. While the outcome of an appeal is presumably unclear to one or both of the litigants, there is comparatively far less information remaining for the litigating parties to share. Factors other than information deficits or asymmetry contribute to appellate activity. Should errors occur, for example, the trial itself can inject new legal (appellate) uncertainty into a dispute. Various economic factors cut in opposing directions. On the one hand, insofar as both parties at the appellate stage have already invested in the cost of a full trial, marginal costs incident to an appeal are generally less than the cost of a trial. On the other hand, after spending money necessary for a trial, perhaps fewer financial resources remain for an appeal.

Efforts to test ADR program efficacy require careful attention to research design considerations. Findings from studies that simply compare disposition times for cases that settle incident to ADR participation with cases that do not settle, for example, reveal little in terms of ADR participation's independent influence on a case's disposition time and related litigation costs. After all, cases that settle almost always do so in less time than cases that are tried to a judge, jury, or appellate panel regardless of ADR participation. ${ }^{15}$ A more probative comparison involves cases that settled and those that were tried while holding constant ADR participation.

Research design challenges aside, results from most empirical assessments of ADR program efficacy are mixed. ${ }^{16}$ Research design complexities contribute to lingering questions about whether ADR programs deliver increased settlement rates and decreased case disposition times. Reflecting the distribution of ADR programs and activity, studies of ADR efficacy in the pretrial context dominate the published research literature.

This study builds on the existing research by exploring whether appellate ADR programs stimulate settlement and reduce disposition time in a national sample of state civil appeals. Two general findings emerge from this study and provide mixed support for

\footnotetext{
${ }^{14}$ See Wayne D. Brazil, Settling Civil Suits 44-46 (1985); Ignazio J. Ruvolo, Appellate Mediation—“Settling” the Last Frontier of ADR, 42 San Diego L. Rev. 177, 180-92 (2005) (describing civil ADR efforts in California's state appellate courts).
}

\footnotetext{
${ }^{15} \mathrm{~A}$ stronger form of the pro-ADR argument suggests that, in some circumstances, even unsuccessful ADR participation might reduce overall case disposition time by helping litigants identify and, therefore, more efficiently litigate over contested issues. See, e.g., Ruch-Alegant, supra note 10.
}

\footnotetext{
${ }^{16}$ For empirical assessments of ADR program efficacy in the trial court setting, see, e.g., James S. Kakalik et al., Just, Speedy, and Inexpensive? An Evaluation of Judicial Case Management Under the Civil Justice Reform Act, 49 Ala. L. Rev. 17, 18, 41 (1997) (assessing a RAND Corp. study and concluding that the federal pilot program had little effect on reducing litigation costs or disposition time); Michael Heise, Justice Delayed?: An Empirical Analysis of Civil Case Disposition Time, 50 Case W. Res. L. Rev. 813 (2000) (finding that ADR participation did not correlate with reduced case disposition time). For a more sanguine view of ADR's efficacy, see, e.g., Brazil, supra note 2, at 249-50. For a summary of the literature, see generally Carl Tobias, Civil Justice Delay and Empirical Data: A Response to Professor Heise, 51 Case W. Res. L. Rev. 235 (2000). For assessments of ADR efficacy in the appellate setting see, e.g., Fetty, supra note 3, at 328-31 (noting varying success rates across years in the Michigan program); Nicole L. Waters \& Michael Sweikar, Efficient and Successful ADR in Appellate Courts: What Matters Most? 62 Disp. Resol. J. 42, 52 (2007) tbl. 4 (finding that increased programmatic integration enhanced settlement rates).
} 
the hypotheses. First, for those appellants included in my study, participation in an ADR program increased the likelihood of a settlement. Second, ADR program participation did not influence disposition time.

Section II briefly considers the theoretical rationales for ADR programs, identifies two key hypotheses concerning the influence of ADR programs on litigation, and briefly summarizes the existing empirical literature. Section III describes the data, methodology, and research design. Section IV presents descriptive results with a particular emphasis on the contours of the stream of appeals through the ADR and appellate court processes. Section V presents regression results that both confirm and supply more textured refinement of the core results in Section IV. The discussion considers how courts' institutional interests are nonetheless served by mandating ADR programs that achieve part of their objectives. Section VI concludes.

\section{Theoretical Justifications for ADR Programs AND RELATED EMPIRICAL Literature}

Law and economic theory supplies one rationale for ADR programs and participation in them as well as generates two key hypotheses: ADR participation stimulates case settlement and reduces disposition time. Existing empirical evidence on whether ADR programs deliver on their central promises, drawn mainly from studies of ADR in the pretrial setting, provides mixed support for the hypotheses.

\section{A. ADR Theory}

A law and economics rationale seeking to account for the emergence of ADR programs generates specific hypotheses that warrant empirical testing. According to Steven Shavell, ex ante ADR participation agreements work to the mutual benefit of parties by reducing the overall cost of resolving disputes. ${ }^{17}$ Sources of cost reduction from ADR participation include the increased probability of settlement and reduced case disposition time.

Nested within theories explaining rationales for ADR program growth are various (and sometimes competing) theories seeking to explain why some cases settle. If, as Priest and Klein assert, trials are most likely to occur in "close" cases ${ }^{18}$ or, as Shavell describes, where the litigants' perspectives of their respective legal positions diverge, ${ }^{19}$ it follows that settlement is most likely in cases that are not close or where litigants' perspectives on a dispute's expected outcome substantially converge. Others advance alternative reasons for case settlement. According to Mnookin and Kornhauser and Cooter, for example, settlement behavior is better understood as a function of bargaining between and among

\footnotetext{
${ }^{17}$ Shavell, supra note 1 , at 2.

${ }^{18}$ Priest \& Klein, supra note 12 , at $12-17$.

${ }^{19}$ Shavell, supra note 1 , at 11 .
} 
litigating parties. ${ }^{20}$ Based on a sample of state civil filings, Gross and Syverud suggest another understanding of settlement activity by emphasizing the nature of the litigating parties and their relationships as well as the influence of insurance and how it bears on damages and settlement authority. ${ }^{21}$ After comparing final settlement offers with actual jury awards where final settlement offers were rejected, Rachlinski concludes that behavioral economics, in general, and framing theory, in particular, explain settlement conduct. ${ }^{22}$ Finally, purely strategic litigation may also influence settlements. ${ }^{23}$ For example, by refusing an otherwise reasonable settlement offer a party can impose additional litigation costs on an opponent by either delaying the final disposition of a case or, in the posttrial context, encumbering a trial court award ${ }^{24}$ or both.

Despite numerous reasons explaining why cases settle, settled cases share at least one salient factor. Settlements are not mandatory, and as a consequence, a settlement arises only if such an outcome is consistent with both parties' interests. How do ADR programs address this factor? ADR programs' principal contribution is the facilitation of information between (and among) disputants. ${ }^{25}$ Increased information generated in a more informal and less adversarial context than formal litigation should afford disputing parties a more accurate perspective on the relative strengths and weaknesses of their case and stimulate bargaining.

Regardless of their motivation, case settlements create private and public benefits. In addition to such private benefits flowing from a more timely and less costly resolution of disputes, the "disappearing trial" trend also permits judges to devote more time and care to a smaller number of cases and relieves time and resource pressure on criminal trials. ${ }^{26}$

In an effort to internalize the private and public benefits offered by ADR, litigants and courts increasingly demand ADR. To examine whether the increased demand for ADR

\footnotetext{
${ }^{20}$ See, e.g., Robert H. Mnookin \& Lewis Kornhauser, Bargaining in the Shadow of the Law: The Case of Divorce, 88 Yale L. J. 950 (1979); Robert Cooter et al., Bargaining in the Shadow of the Law: A Testable Model of Strategic Behavior, 11 J. Legal Stud. 225 (1982).

${ }^{21}$ Samuel R. Gross \& Kent D. Syverud, Getting to No: A Study of Settlement Negotiations and the Selection of Cases for Trial, 90 Mich. L. Rev. 319, 322 (1991). A study of medical malpractice closed claims in Texas notes the influence of malpractice insurance policy limits on differences between what juries award and what prevailing plaintiffs receive. See David A. Hyman et al., Do Defendants Pay What Juries Award? Post-Verdict Haircuts in Texas Medical Malpractice Cases, 1988-2003, 4 J. Empirical Legal Stud. 3 (2007).
}

${ }^{22}$ See Jeffrey Rachlinski, Gains, Losses and the Psychology of Litigation, 70 S. Cal. L. Rev. 113, 114, 118, 120, 142 (1996).

${ }^{23}$ See, e.g., Lynn M. LoPucki \& Walter O. Weyrauch, A Theory of Legal Strategy, 49 Duke L. J. 1405, 1416 (2000) (noting various strategic aspects incident to the Texaco-Pennzoil appeal).

${ }^{24}$ See, e.g., Harlon L. Dalton, Taking the Right to Appeal (More or Less) Seriously, 95 Yale L. J. 62, 85 (1985) (noting various reasons motivating a party's decision to file an appeal).

${ }^{25}$ To be sure, the less formal and less adversarial setting provided by ADR might also play some role as well.

${ }^{26}$ John Lande, How Much Justice Can We Afford?: Defining the Courts' Roles and Deciding the Appropriate Number of Trials, Settlements, and Other Elements Needed to Administer Justice, 2006 J. Disp. Resol. 213,228 (2006). 
enjoys empirical support, this article explores whether ADR delivers on the two core benefits predicted by ADR proponents as well as by law and economic theory. ADR participation is premised on twin rationales, previously described, that translate into the following two hypotheses.

$\mathrm{H}_{1}$ : ADR participation increases the likelihood of settlement.

$\mathrm{H}_{2}$ : ADR participation reduces disposition time.

\section{B. Evidence on ADR Program Efficacy}

Although most researchers agree that empirical research on the efficacy of ADR is scant, ${ }^{27}$ findings on settlements and disposition time are mixed and focus on the trial-court level. In a recent review of empirical studies of 27 general civil litigation court-connected ADR programs, Wissler found that settlement rates ranged from 27 to 63 percent. ${ }^{28}$ Of the 27 studies in her review, however, only eight included a control group of non-ADR cases. Of those eight studies, approximately one-half found no difference in settlement rates between ADR and non-ADR cases. The other half of studies found that ADR cases "tended to have a somewhat higher rate of settlement or a somewhat lower rate of trial judgment on a dispositive motion." ${ }^{29}$

Similarly mixed empirical findings characterize the relation between ADR participation and case disposition time. Wissler's literature review includes 10 studies that considered disposition time for court-connected ADR programs involving general civil litigation cases. Of the 10 studies, five found that ADR participation cases terminated faster than non-ADR cases. Of the five other studies, four reported no difference in terms of case disposition time and one study found that ADR participation increased disposition time.

Empirical studies of ADR programs in the appeals context, while helpful, are far fewer in number and comparatively limited in scope. A recent study of the effectiveness of court-annexed state appellate ADR programs explored the efficacy of case screening as a way to increase settlement rates. Although the Waters and Sweikar paper found that increasing court supervision of and engagement with ADR programs increased settlement prospects, ${ }^{30}$ the paper found no evidence that ADR screening efforts, designed to identify and direct promising appeals to ADR programs, ${ }^{31}$ promoted

\footnotetext{
${ }^{27}$ See Lisa B. Bingham, Why Suppose? Let's Find Out: A Public Policy Research Program on Dispute Resolution, 2002 J. Disp. Resol. 101 (2002); Deborah R. Hensler, ADR Research at the Crossroads, 200 J. Disp. Resol. 71 (2000); Thomas J. Stimpanowich, ADR and the "Vanishing Trial": The Growth and Impact of "Alternative Dispute Resolution,” 1 J. Empirical Legal Stud. 843 (2004).

${ }^{28}$ Roselle L. Wissler, The Effectiveness of Court-Connected Dispute Resolution in Civil Cases, 22 Conflict Resol. Q. 55, 65 (2004).

${ }^{29} \mathrm{Id}$.

${ }^{30}$ See Waters \& Sweikar, supra note 16 , at 52 , tbl.4.

${ }^{31}$ Just because an appeal was referred to an ADR program did not mean that the litigants actually participated. See id. at 48 (most, but not all, appellants and appellees referred to ADR participated).
} 
settlement. ${ }^{32}$ Notably, however, the Waters and Sweikar study did not address whether ADR participation increased settlement prospects or reduced disposition time.

By examining whether ADR participation correlates with appeals settlement and case disposition time in the state civil appeals context, this study builds on existing ADR research in important ways. Results from this study contribute to a comparatively understudied sector of litigation activity (the appellate sector) and facilitate comparisons about possible ADR efficacy differences between the trial and appellate systems. In addition, this study makes an important methodological contribution by comparing a subsample of appeals that did not participate in ADR programs with a subsample of appeals that did participate in ADR programs.

\section{Data, Methodology, and Research Design}

Two distinct, though related, data sets supply the data necessary for this study. First, the "Civil Justice Survey of State Courts," a project of the National Center for State Courts (NCSC) and the U.S. Department of Justice's Bureau of Justice Statistics (BJS), gathers data directly from state court clerk offices on tort, contract, and property cases disposed of by trial during calendar year 2001. The 2001 data set covers state courts of general jurisdiction in a random sample of 46 of the nation's 75 most populous counties. The 75 counties from which the sample of 46 was drawn include approximately 37 percent of the 1990 U.S. population and about one-half of all civil lawsuits filed in state courts. ${ }^{33}$ The 2001 data set includes information on 8,038 completed trials. ${ }^{34}$

The second data set used in this study complements the first. NCSC and BJS implemented a follow-up study that supplemented the 2001 trial study by tracking the 1,204 cases where the trial verdict or judgment, concluded by trial during calendar 2001, was appealed to an intermediate appellate court or a state's court of last resort by April 2005. ${ }^{35}$ Of this

\footnotetext{
${ }^{32}$ Id. at 51, tbl.3.

${ }^{39}$ For a general discussion, see Bureau of Justice Statistics Bulletin: Civil Justice Survey of State Courts, 2001: Civil Trial Cases and Verdicts in Large Counties, 2001 (Apr. 2004) [hereinafter "BJS, Trials 2001"]. For a more technical source and the data set codebook, see Bureau of Justice Statistics, U.S. Dep't of Justice, Civil Justice Survey of State Courts, 2001 (Inter-Univ. Consortium for Pol. \& Soc. Research, No. 3957, June 2004) [hereinafter "ICPSR, Trials 2001"]. See also Eisenberg et al., Juries, Judges, and Punitive Damages: Empirical Analyses Using the Civil Justice Survey of State Courts 1992, 1996, and 2001 Data, 3 J. Empirical Legal Stud. 263, 267-68 (2006) (describing the 1992, 1996, and 2001 data sets); Catherine M. Sharkey, Unintended Consequences of Medical Malpractice Damage Caps, 80 N.Y.U. L. Rev. 391, 446-50 (2005) (same).
}

\footnotetext{
${ }^{34}$ Although the 2001 study's final sample includes 8,311 cases (see ICPSR, Trials 2001, supra note 33, at 4), the data set includes usable information on 8,038 cases. See id. at 5 (noting the final data set includes 8,038 cases); Sharkey, supra note 33, at 446 ("The 2001 dataset includes 8038 cases.").

${ }^{35}$ For a general description of the appeals data set, see Bureau of Justice Statistics Bulletin: Appeals from General Civil Trials in 46 Large Counties, 2001-2005 (Jul. 2006) [hereinafter "BJS, Appeals"]. Of the 1,204 cases that involved an appeal, 15 (or 1.5 percent) remained pending at the end of the April 2005 study period. Id. at 1.
} 
universe of 1,204 appeals, 47 appeals (3.9 percent) were excluded from many of my analyses because the appeals lacked critical information about which party prevailed at trial.

Because this study dwells on traditionally adverse appeals from trial court decisions, cases where it was not clear that the nature of the appeal was adverse were excluded from the sample. For example, if the trial court ruled for the plaintiff, most would expect that the defendant would be the appellant in any appeal. Conversely, where the trial court ruled for the defendant, one would expect the plaintiff to be the appellant. For the most part (in 83.4 percent of the appeals), these expectations were met. Excluding a small subgroup of nonadverse appeals generates a universe of 965 usable appeals and permits a more accurate picture of appeals by plaintiffs and defendants from trial court judgments entered against them. The appeal rate, drawn from the pool of adverse appeals, is the percentage of trial court judgments for one party or the other that the losing party puts onto the appellate docket. $^{36}$

Merging the two NCSC and BJS data sets generates a unique source of data: a longitudinal view of the universe of state appellate activity drawn from the most representative sample of state trial activity in the United States. These data facilitate the systematic study of appeals of trials and the potential influence of ADR participation on key outcomes. ${ }^{37}$ With direct access to the state court clerk offices, as well as approximately 100 trained coders recording data, the data set avoids traditional limitations incident to relying on litigants or third parties to report. Self-reports, common in many commercial verdict reporters, typically overstate plaintiff win rates and damage award levels. ${ }^{38}$

Research on ADR program efficacy typically runs into a substantial research design quandary. For disputes routed through an ADR program, researchers can only guess about a dispute's outcome had it remained exclusively in the formal adjudication system. Uncertainty about the counterfactual persists and confounds analyses about the independent influence, if any, of ADR program participation on case settlement or disposition time. The research design used in this study addresses some of the counterfactual uncertainty in various ways.

Specifically, the appeals data set breaks cleanly into two discrete subgroups along a dependent variable of interest: one group of cases that settled before an appeals court decision $(N=416)$ and a second group of appeals that resisted settlement and persisted to a formal appeals court decision $(N=549)$. Distributed between these two subgroups of appeals are the 166 appeals in which the litigants participated in an ADR program. The

\footnotetext{
${ }^{36}$ For a similar approach to defining the appeal rate, see Kevin M. Clermont \& Theodore Eisenberg, Appeal from Jury or Judge Trial: Defendants' Advantage, 3 Am. L. \& Econ. Rev. 125, 129 (2001).

${ }^{37}$ See, e.g., BJS, Appeals, supra note 35. If one includes the mixed appeals, then the overall appellate rate is 14.4 percent. We do not compute reversal rates using these mixed appeals because of the ambiguity of which party benefited.

${ }^{38}$ See, e.g., Theodore Eisenberg et al., The Predictability of Punitive Damages, 26 J. Legal Stud. 623,614 n.53 (1997) (finding bias in commercial verdict reporter samples); Deborah Jones Merritt \& Kathryn A. Barry, Is the Tort System in Crisis? New Empirical Evidence, 60 Ohio St. L. J. 315, 324-26 (1999) (same); Erik K. Moller et al., Punitive Damages in Financial Injury Jury Verdicts, 28 J. Legal Stud. 283, 335 (1999) (reporting reasonable levels of confidence in the jury verdict reporters but acknowledging some potential bias).
} 
distribution generates something close to a quasi-experimental research design ${ }^{39}$ and facilitates comparing cases that settled (along with their disposition times) with those that did not while controlling for whether the appeal participated in an ADR program. Through descriptive comparisons as well as more formal modeling we can better assess the influence of ADR programs as it relates to the appeals settlement outcome and on disposition time.

Despite the state civil appeals data set's unique strengths, it is not without limitations. For example, the data are limited to tried cases and therefore do not include cases appealed after dispositive pretrial motions. Also, because the sample focuses on the nation's largest counties and state courts of general jurisdiction, the data might not convey those aspects of the civil justice system, if any, peculiar to smaller counties or rural areas or to cases heard in special jurisdiction courts. ${ }^{40}$ Moreover, the focus on state courts precludes generating implications for federal courts. Finally, this study of settlement activity is limited to the appellate context. These cases, by definition, resisted settlement during the trial stages and persisted into the appellate stage. Whether findings from this study of appeals context are germane to the preappeals context requires further study.

As Table 1 illustrates, cases navigated through an array of filters as they proceeded from the civil dispute stage through the trial and appellate processes. As only a small fraction of civil actions filed reach trial, the pool of tried cases may systematically differ from the larger pool of civil disputes from which they emerged. The appeals process itself imposed additional filters. Only 12 percent of the tried civil cases initiated the appeals process. Fewer cases still (6.8 percent) pursued the appeals process to decision. That is, of the cases that began the appeals process, just over one-half (56.9 percent) completed at least one level of review: disposition by an intermediate appellate court.

There are strong theoretical reasons to expect selection effects to result in a nonrandom sample of cases on appeal. Expectations theory predicts that objectively strong and weak civil cases will settle or reach conclusion prior to being resolved at trial. ${ }^{41}$ Litigants that take cases to trial do so partly because they can afford to pursue trial litigation and, presumably, because they sense some reasonable level of uncertainty-factual or legal-as to a case's outcome. ${ }^{42}$ The subpool of cases that withstands settlement or withdrawal, motions for directed verdicts and summary judgment, and other dispositions more likely

${ }^{39}$ Court-level ADR case screening policies and practice, however, preclude a purely nonbiased stream of ADR appeals.

\footnotetext{
${ }^{40}$ Despite the absence of a clear theoretical explanation, the influence of geography, and whatever that might entail, remains a consistent finding in the research literature. See, e.g., Eisenberg, supra note 38, at 630-31 n.26 (finding geography relevant to punitive damages); Teresa A. Sullivan et al., As We Forgive Our Debtors: Bankruptcy and Consumer Credit in America 339-40 (1989) (geography influencing bankruptcy filings); Michael Heise, Justice Delayed?: An Empirical Analysis of Civil Case Disposition Time, 50 Case W. Res. L. Rev. 813, 836-38, 847-48 (2000) (noting a geographic influence on case disposition time). The influence of geography is not limited to U.S. courts. See, e.g., Eisenberg, supra note 38, at 631 n.26 (finding a geographic effect in courts in Japan, Sweden, and Finland).

${ }^{41}$ E.g., Theodore Eisenberg, Litigation Models and Trial Outcomes in Civil Rights and Prisoner Cases, 77 Geo. L. J. 1567, 1571 (1989).
}

${ }^{42}$ Professors Priest and Klein, among others, previously articulated and developed this point. See generally Priest \& Klein, supra note 12. 
Table 1: State Trials, Appeals, and Settlements

\begin{tabular}{|c|c|c|c|c|c|c|c|c|}
\hline & $\begin{array}{c}\text { Trial } \\
\text { Court } \\
\text { Decisions }\end{array}$ & $\begin{array}{c}\text { Trial } \\
\text { Court } \\
\text { Decisions } \\
(\%)\end{array}$ & $\begin{array}{l}\text { Appeals } \\
\text { Filed }\end{array}$ & $\begin{array}{c}\text { Appeals } \\
\text { Filed } \\
(\%)\end{array}$ & $\begin{array}{l}\text { Appeals } \\
\text { Settled }\end{array}$ & $\begin{array}{c}\text { Appeals } \\
\text { Settled } \\
(\%)\end{array}$ & $\begin{array}{l}\text { Appeals } \\
\text { Concluded }\end{array}$ & $\begin{array}{c}\text { Appeals } \\
\text { Concluded } \\
(\%)\end{array}$ \\
\hline All cases & 8,038 & & 965 & & 416 & & 549 & \\
\hline Jury trial & 6,165 & 76.7 & 703 & 72.85 & 296 & 71.15 & 407 & 74.13 \\
\hline Judge trial & 1,873 & 23.3 & 262 & 27.15 & 120 & 28.85 & 142 & 25.87 \\
\hline $\begin{array}{l}\text { ADR participant } \\
\text { Party appealing }\end{array}$ & & & 166 & 17.2 & 89 & 21.39 & 77 & 14.03 \\
\hline Defendant & 4,351 & & 551 & 57.1 & 262 & 62.98 & 289 & 52.64 \\
\hline Plaintiff & 3,677 & & 414 & 42.9 & 154 & 37.02 & 260 & 47.36 \\
\hline Case type & & & & & & & & \\
\hline Motor vehicle & 2,819 & 35.07 & 114 & 11.81 & 60 & 14.42 & 54 & 9.84 \\
\hline $\begin{array}{l}\text { Assault, slander, } \\
\text { libel }\end{array}$ & 312 & 3.88 & 48 & 4.97 & 21 & 5.05 & 27 & 4.92 \\
\hline Product liability & 117 & 1.46 & 30 & 3.11 & 9 & 2.16 & 21 & 3.83 \\
\hline $\begin{array}{l}\text { Dangerous } \\
\text { premises }\end{array}$ & 924 & 11.5 & 92 & 9.53 & 38 & 9.13 & 54 & 9.84 \\
\hline $\begin{array}{l}\text { Medical } \\
\text { malpractice }\end{array}$ & 850 & 10.57 & 129 & 13.37 & 56 & 13.46 & 73 & 13.3 \\
\hline Prof. malpractice & 68 & 0.85 & 21 & 2.18 & 7 & 1.68 & 14 & 2.55 \\
\hline Other tort & 361 & 4.49 & 65 & 6.74 & 20 & 4.81 & 45 & 8.2 \\
\hline $\begin{array}{c}\text { Employment } \\
\text { contract }\end{array}$ & 281 & 3.5 & 83 & 8.6 & 31 & 7.45 & 52 & 9.47 \\
\hline Fraud & 428 & 5.32 & 78 & 8.08 & 37 & 8.89 & 41 & 7.47 \\
\hline Lease & 188 & 2.34 & 26 & 2.69 & 13 & 3.13 & 13 & 2.37 \\
\hline Seller plaintiff & 772 & 9.6 & 118 & 12.23 & 63 & 15.14 & 55 & 10.02 \\
\hline Buyer plaintiff & 531 & 6.61 & 89 & 9.22 & 39 & 9.38 & 50 & 9.11 \\
\hline Other contract & 211 & 2.63 & 36 & 3.73 & 16 & 3.85 & 20 & 3.64 \\
\hline Property & 176 & 2.19 & 36 & 3.73 & 6 & 1.44 & 30 & 5.46 \\
\hline$N$ & 8,038 & 8,038 & 965 & 965 & 416 & 416 & 549 & 549 \\
\hline
\end{tabular}

Source: U.S. Dep't of Justice, Bureau of Justice Statistics. Supplemental Survey of Civil Appeals, 2001 (ICPSR 4539).

comprises cases whose underlying merits reside somewhere in the "gray middle area." A similar set of filters arise anew during the posttrial appeals process. ${ }^{43}$ These various selection filters influence the case stream over time and in a manner that generates a skewed subset of appeals. The data permit an assessment of one aspect of the selection process: the decision to undertake an appeal after trial. A selection model (Heckman) is used to exploit the data and account for this filtering.

Two additional factors influenced the stream of appeals that participated in ADR programs. One factor involves geography. Specifically, of the 46 sampled large counties, 38

\footnotetext{
${ }^{43}$ Id. at 29 (arguing that aside from possible precedential concerns, selection effect applies "indistinguishably to trial and appellate disputes").
} 
(86.2 percent) operated ADR programs. ${ }^{44}$ Second, in the 38 counties where ADR programs were available, individual appellate courts retained broad latitude in terms of deciding which cases to recommend to ADR. Appeals screeners were used in various ways in some jurisdictions to help appellate courts identify and route promising appeals into ADR programs. The Waters and Sweikar study describes various factors that influenced screeners across participating counties. ${ }^{45}$ Although Waters and Sweikar found that screeners' efforts to divert "appropriate" appeals (or appeals seemingly amenable to settlement) to ADR did not correspond with ADR success (settlement) ${ }^{46}$ the distribution of appeals that did and did not participate in ADR programs is assumed to be nonrandom. The assumed nonrandom distribution tilts in a direction favoring the desired outcomes for ADR programs. That is, if one assumes that case screeners systematically directed appeals especially prone or amenable to settlement into the ADR programs (contrary to results from the Waters and Sweikar study $\left.{ }^{47}\right)$, one would expect this to exert upward pressure on the settlement rate. Consequently, results consistent with ADR desired influences (increased settlement and reduced disposition time) must be interpreted cautiously in light of the presumed nonrandom appeal routing. Conversely, results inconsistent with ADR desired influences, however, can be interpreted with greater confidence.

\section{INITIAL OBSERVATIONS}

As Table 1 illustrates, the universe of 8,038 completed trials generated 965 appeals (or 12 percent of the completed trials). Of the 965 appeals, 416 settled and the remaining 549 resulted in an appeals court decision. This study focuses on two subpools of the 965 appealed cases. Of the 965 cases that initiated an appeal, 17.2 percent (166) participated in an ADR program. These two subgroups-appeals that settled (416) and appeals that did not (549) — varied in terms of ADR participation as well as two key outcomes: settlement and disposition time (measured in days).

\section{A. Settlements}

The 166 appeals that participated in ADR programs distributed close to evenly between those that settled (53.6 percent) and those appeals that persisted to an appellate court decision (46.4 percent) notwithstanding ADR participation. The distribution of settled cases controlling for ADR participation hints at systematic differences. ${ }^{48}$ Table 2 illustrates

\footnotetext{
${ }^{44}$ These 38 counties handled 63.8 percent (or 616) of the appeals in my data set.

${ }^{45}$ Waters \& Sweikar, supra note 16 , at $46-48$

${ }^{46}$ Id. at 52, tbl. 4 .

${ }^{47}$ Id.

${ }^{48} \mathrm{~A}$ simple nonparametric analysis suggests that a statistical relation exists. Chi-square coefficient $=9.022 ; p=0.003$.
} 
Table 2: Appeals Settled and Concluded by ADR Participation

\begin{tabular}{lcc}
\hline & Appeal Settled & Appeal Concluded \\
\hline ADR participation & 89 & 77 \\
No ADR & 327 & 472 \\
$N$ & 416 & 549 \\
\hline
\end{tabular}

NotE: The significance of the difference between settled and concluded appeals controlling for ADR participation is based on a chi-square test.

Source: U.S. Dep't of Justice, Bureau of Justice Statistics, Supplemental Survey of Civil Appeals, 2001 (ICPSR 4539).

Table 3: Appeal Disposition Time (Square-Root Days) by ADR Participation

\begin{tabular}{lcccr}
\hline & Mean & Median & SD & N \\
\hline ADR attended & 16.28 & 15.94 & 6.05 & 166 \\
No ADR & 17.53 & 18.52 & 6.65 & 764 \\
Significance of ADR-No ADR difference & 0.026 & 0.013 & 0.133 & 930 \\
\hline
\end{tabular}

Notes: The significance of means difference is based on a $t$ test; the significance of medians differences is based on a Mann-Whitney test; the significance of standard deviations is based on an $f$ test.

Source: U.S. Dep't of Justice, Bureau of Justice Statistics, Supplemental Survey of Civil Appeals, 2001 (ICPSR 4539).

that the number of appeals that settled and participated in ADR programs exceeds the number that random chance would predict. Thus, Table 2 implies that ADR programs succeeded in terms of promoting settlement.

\section{B. Disposition Time}

ADR programs also promise to reduce disposition time. To assess whether this promise was realized, the number of days between the filing of an appeal and its disposition (achieved either through a settlement or appellate court decision) serves as the dependant variable of interest. The analyses use the square-root of the raw number of days as this transformation is necessary to comply with standard regression assumptions. ${ }^{49}$

Table 3 summarizes appeal disposition time by ADR participation to facilitate comparisons. Although the standard deviations for the two groups do not differ significantly, significant differences do emerge for the groups' means and medians.

Figure 1 provides a kernel density estimate ${ }^{50}$ for appeal disposition time. Visual inspection reveals that despite the observed distribution possessing a bit more "spread," on balance the dependent variable-disposition time, expressed by the square-root of the raw number of days-distributes in a manner that approximates a normal distribution.

\footnotetext{
${ }^{49}$ For a discussion of the need for transformations to satisfy regression assumptions, see Theodore Eisenberg \& Martin T. Wells, The Significant Association Between Punitive and Compensatory Damages in Blockbuster Cases: A Methodological Primer, 3 J. Empirical Legal Stud. 175 (2006).
}

${ }^{50}$ Figure 1 generated with the "kdensity" command with the "bwidth(3)" option, in Stata 10.0. For a discussion of kernel density estimation, see generally B. W. Silverman, Density Estimation for Statistics and Data Analysis (1986). 
Figure 1: Kernal density estimate for appeal disposition time.

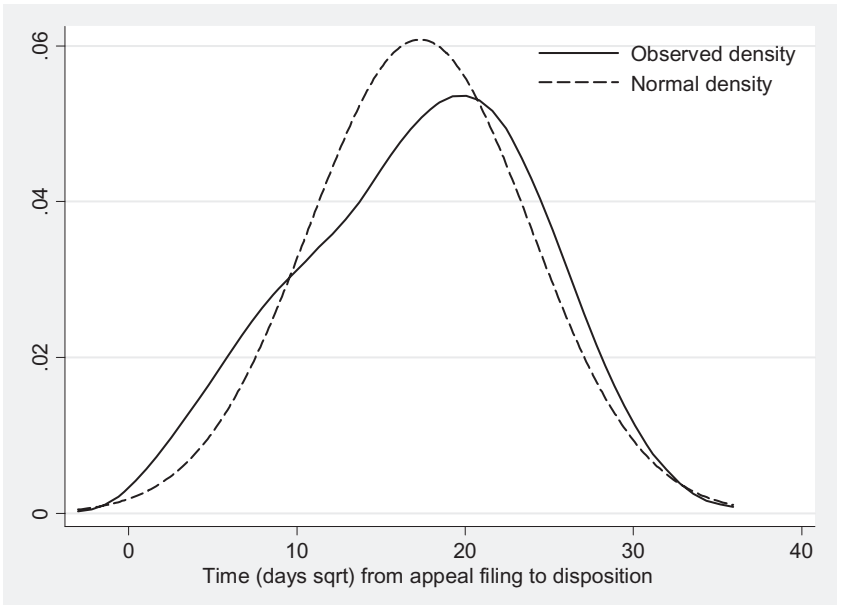

Note: $N=965$.

SourCE: U.S. Dep't of Justice, Bureau of Justice Statistics, Supplemental Survey of Civil Appeals, 2001 (ICPSR 4539).

Figure 2 supplies further texture to Figure 1 by comparing the distributions of disposition time for appeals that participated in ADR programs and appeals that did not. As Figure 2 illustrates, the principal differences include some slight disturbance in the ADR participation distribution and, more important, the "left-shift" of the ADR participation distribution relative to the distribution for appeals that did not participate in ADR programs. At the descriptive level, what is suggested are slight yet noticeable differences in the distribution of disposition times for appeals that participated in ADR programs and those appeals that did not. ${ }^{51}$

Figure 3 presents a slightly different perspective on the ADR participation versus no-ADR participation comparison presented in Figure 2. Similar to Figure 2, Figure 3 compares disposition time attributes for appeals that participated in ADR programs with those appeals that did not. Also similar is that Figure 3 suggests visible though sometimes subtle differences in disposition time between appeals that participated in ADR and those that did not. Overall, the median (the single lines inside the boxes) disposition time for the ADR participation appeals is lower than the median for their non-ADR counterparts. The two subgroups of appeals are most similar, however, in terms of the spread between the 25th and 75th percentiles (the upper and lower borders of the boxes).

Taken together, Figures 1, 2, and 3 and Table 3 illustrate, and common sense suggests, that the average settled appeal took less time to conclude than the average appeal pursued to a court decision. What these figures and the table largely mask, however, is

\footnotetext{
${ }^{51}$ Results from a Kolomogorov-Smirnov test suggest a statistically significant difference between the two distributions $(p=0.005)$.
} 
Figure 2: Kernal density estimates by ADR participation.

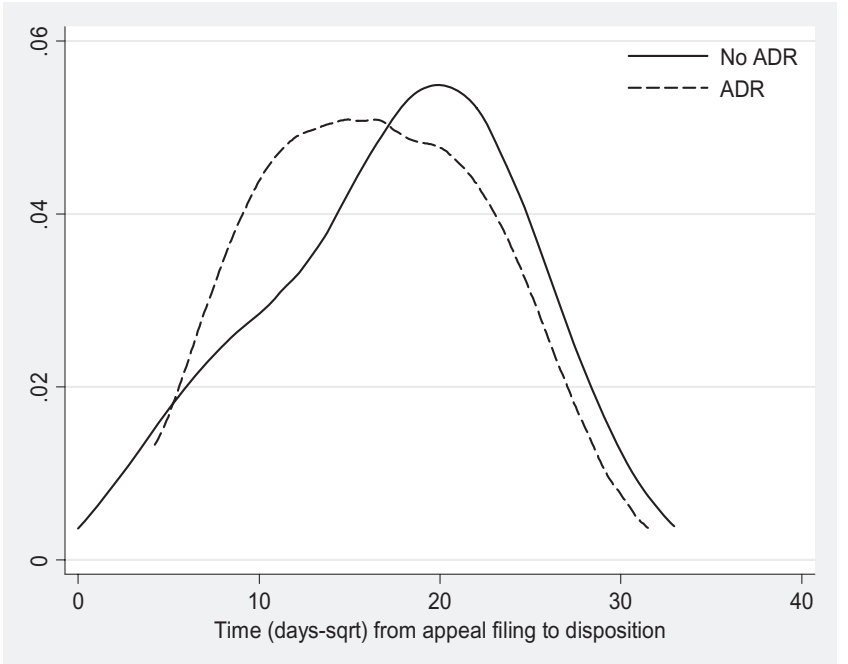

Note: $N=965$.

Source: U.S. Dep't of Justice, Bureau of Justice Statistics, Supplemental Survey of Civil Appeals, 2001 (ICPSR 4539).

Figure 3: Appeal disposition time (sqrt days) by ADR participation.

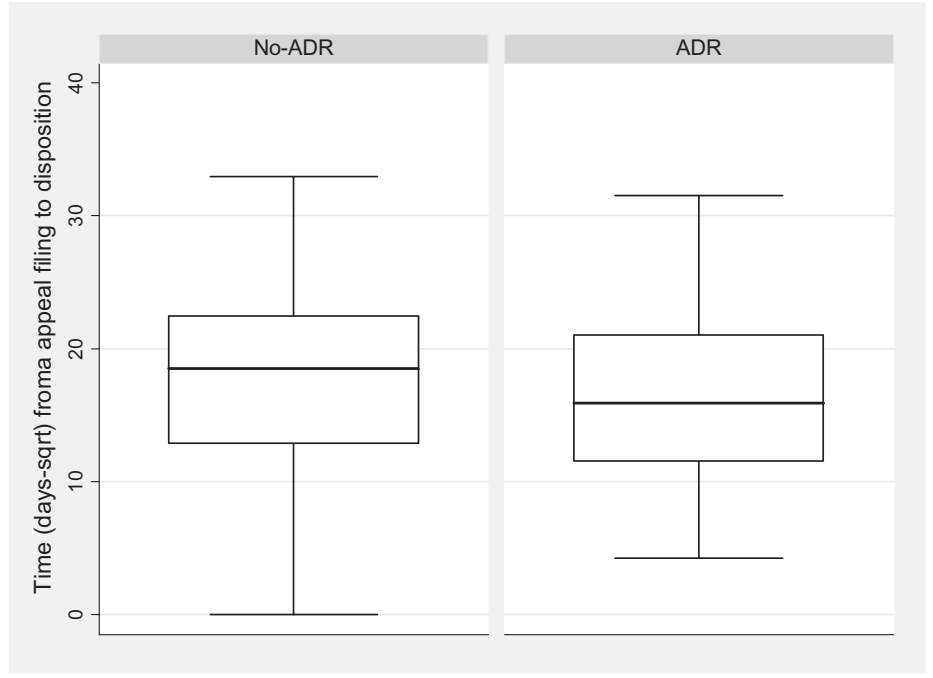

Note: $N=799$ (No ADR); $N=166$ (ADR).

Source: U.S. Dep't of Justice, Bureau of Justice Statistics, Supplemental Survey of Civil Appeals, 2001 (ICPSR 4539). 
Table 4: Average Appeal Disposition Time (Square-Root Days) by ADR Participation and Appeal Outcome

\begin{tabular}{lcc}
\hline & Appeal Settled & Appeal Concluded \\
\hline ADR participation & 11.66 & 21.19 \\
No ADR & 12.22 & 20.96 \\
$N$ & 382 & 548 \\
\hline
\end{tabular}

Note: The significance of means difference in disposition time is based on a $t$ test.

Source: U.S. Dep't of Justice, Bureau of Justice Statistics, Supplemental Survey of Civil Appeals, 2001 (ICPSR 4539).

critical within-group variation. Specifically, within the subgroup of appeals that participated in ADR programs, some appeals settled and other appeals did not. Similarly, among the subgroup of appeals that did not participate in ADR programs, some settled and some did not. Consequently, assessments seeking the independent influence of ADR participation on disposition time need to account (and control) for whether an appeal settled because it is almost always the case that an appeal that settles takes less time to conclude than one that does not settle.

Table 4 begins this inquiry and explores within-group comparisons of mean disposition times between appeals that participated in ADR and those appeals that did not participate, controlling for whether the appeal settled. Results from simple $t$ tests suggest that differences in mean disposition times between appeals that submitted to ADR programs and those that did not, after controlling for whether the appeals settled, do not suggest any systematic differences between these two subgroups of appeals. ${ }^{52}$ In terms of explaining appeal disposition time, Table 4 suggests that, rather than ADR participation, what really matters for disposition time is whether an appeal was fully litigated and generated an appeals court decision. For appeals that settled, those that participated in ADR programs took slightly less time than settled appeals that did not participate in ADR. For appeals that concluded with a court decision, cases that participated in ADR programsalbeit unsuccessfully-took longer to conclude than those that did not. Thus, time invested by litigants in ADR programs that did not ultimately result in a settlement did not yield a net disposition time saving even though the litigants presumably had a clearer idea about their opponents' legal positions and the outstanding contested issues by virtue of having gone through ADR.

\section{Assessing ADR Influence by Modeling Decisions to Appeal and Settle and Disposition Time}

The descriptive results presented in Section IV raise important questions about ADR's potential influence on settlements as well as disposition time for appeals. The asymmetrical

\footnotetext{
${ }^{52} T$ tests uncover no statistical difference between means $(p=0.389$ for the appeals settled group; $p=0.654$ for the appeals concluded group).
} 
distributions of settlements and the symmetrical distribution of mean disposition times raise questions that warrant a more statistically sophisticated effort. Part of such an effort involves accounting for selection effects. A litigant's desire to either settle or pursue an appeal to a judicial decision arises only after the litigant decides to initiate an appeal. The subpool of completed trials that initiated an appeal systematically differs from the bulk of completed trials that did not pursue an appeal in ways that influence the outcome variables of interest-settlement and disposition time.

Notably, defendants and plaintiffs evidenced roughly similar appellate and settlement activity. Although defendants appealed adverse trial court decisions slightly more often than did plaintiffs (12.7 percent vs. 11.3 percent), ${ }^{53}$ this difference did not achieve statistical significance. Similarly, although plaintiffs appealed to conclusion (i.e., resisted settlement) slightly less often than did defendants (7.1 percent vs. 6.6 percent), the difference between plaintiffs and defendants was not significant. ${ }^{54}$ To the extent that cases that persisted through the initial trial by definition resisted whatever efforts were made at resolving the dispute pretrial, however, one would expect that completed trials that initiate the appellate process would be even less amenable to settlement. Similarly, those cases that resisted settlement should, on average, take longer to complete than those that settle. Results presented in Tables 5 and 6 comport with these expectations and suggest the influence of a selection effect.

\section{A. Decisions to Appeal}

What variables should appellate models include? With respect to the decision to appeal, parties' perceptions (correct or not) about how appellate courts react to jury trials compared to bench trials, and to plaintiff trial court wins compared to defendant wins, likely inform litigants. To capture this possibility, the models include dummy variables signaling whether a case was tried to a jury or to a judge, and whether a plaintiff or defendant prevailed.

Also expected is that a state's and particular case type's "reversal culture" influences a decision to pursue an appeal. For each state ${ }^{55}$ and case category I computed an overall reversal rate. For example, the reversal rates in Georgia and New Jersey were 12.5 percent and 56.3 percent, respectively. Similarly, reversal rates for various case types ranged from 50 percent (employment contract cases) to 23.1 percent (lease cases). Holding all else constant, parties seeking to reverse a trial court decision should be more reluctant to pursue an appeal in states with lower reversal rates or involving case types with lower reversal rates.

In addition to varied reversal rates, case types also influence other factors. For example, case types influence decisions regarding the routing of cases to either judges or

\footnotetext{
${ }^{53}$ Id.

${ }^{54} \mathrm{Id}$.

${ }^{55}$ The "(other states)" dummy variable includes six states (GA, HI, MA, NC, VA, and WI) where no more than one appeal was reversed during the timeframe of this study.
} 
juries and display sometime sharply different trial outcomes. ${ }^{56}$ Case types also influence various trial facets, including settlement $\operatorname{rates}^{57}$ and disposition time. ${ }^{58}$ Given case type influence on the civil justice system, it is reasonable to anticipate that case types will influence various aspects of the appeals process as well. Consequently, the models include a dummy variable for each of our 14 case types other than a reference category.

Individuals, corporations, and governments vary in their appetite for and conduct during litigation, ${ }^{59}$ and it is reasonable to assume that such variation persists into the appeals process. To account for this variation, dummy variables identify cases involving corporate plaintiffs, corporate defendants, and governmental plaintiffs. ${ }^{60}$ Litigant characteristics are important regardless of the trial outcome. To the extent that individual litigants believe that corporate litigants behave differently in litigation, for example, such differences would presumably present regardless of whether the corporation won or lost at trial. Moreover, because litigants' decisions about whether to appeal may vary over time, the models include the year the lawsuit was initially filed to help control for any linear time trend in the data. Finally, to account for those states that include more than one of the sampled large counties, a dummy variable serves as a check on possible differences between those states and states with one sampled county. This is warranted because states with more than one large county (e.g., California) might plausibly behave differently than other states with only one large county in the sample.

\section{B. Decisions to Settle}

Efforts to model settlement decisions call for a similar, though slightly different, set of independent variables. Analyzing the determinants of whether an appeal settled is a principal interest and, among the array of plausible independent variables, the primary focus involves participation in an ADR program. Obviously, the availability of ADR programs is one critical control factor. Moreover, the number of appellants and appellees serves as crude proxy for case complexity, which plausibly influences settlement prospects.

Also included in the settlement model are such variables as case type, party type, and year appeal filed. These standard variables are included given their import for the decision to file an appeal as well as the trial court outcome. To account for possible state-level effects on the appellate outcome, the models include dummy variables for each state, as well as a dummy variable signaling those states that have more than one sampled large county.

\footnotetext{
${ }^{56}$ See, e.g., Kevin M. Clermont \& Theodore Eisenberg, Trial by Jury or Judge: Transcending Empiricism, 77 Cornell L. Rev. 1124, 1137-38, 1167-70.

${ }^{57}$ Eisenberg \& Heise, supra note 13, at 14, tbl.2.

${ }^{58}$ See, e.g., Heise, supra note 16 , at $839-42$.

${ }^{59}$ E.g., Theodore Eisenberg \& Henry Farber, The Government as Litigant: Further Tests of the Case Selection Model, 5 Am. Law \& Econ. Rev. 94 (2003).
}

${ }^{60}$ These particular pairings were used to tether findings from this study to those of prior studies. In any event, the inclusion of alternative pairings does not disturb core findings. 
Finally, because outcomes of individual appeals within a state might not be independent of one another, appeals are treated as clustered at the county level, resulting in adjusted standard errors.

\section{Modeling Appeal Disposition Time}

What helps explain how long it takes to conclude an appeal? Insofar as decisions about appealing a trial court decision influence an appeals total disposition time, appeal disposition time and settlement models share many, if not most, variables. Consequently, the disposition time model includes independent variables relating to ADR participation, case complexity, trial outcome, case type, litigant pairs, and state dummy variables. One critical variable that distinguishes the disposition time and appeal decision models is a dummy variable signaling whether the appeal settled. This independent variable is crucial for two reasons. First, common sense and experience suggest that appeals that settle take less time than those that do not. ${ }^{61}$ Second, including variables on ADR participation and settlement permits the model to assess the influence, if any, of ADR participation on disposition time independent of whether the appeal settled.

\section{Results and Discussion}

Results from this study indicate that participation in an ADR program correlates with an increased likelihood of settlement but not reduced disposition time. Given the case screening that took place in some jurisdictions, the absence of reduced disposition time is especially notable.

\section{Settlement}

To assess the likelihood of an appeal settling prior to an appeals courts reaching a formal judicial conclusion, I estimate a selection (Heckman) model with a dependent variable equal to 1 if an appeal is settled and 0 otherwise. ${ }^{62}$ The selection model includes all tried cases. Table 5 reports results from the model for settlement (the second stage of the selection model) ${ }^{63}$ The findings show that, consistent with my descriptive findings, ADR program participation positively correlates with settlement.

\begin{tabular}{|c|c|c|c|c|c|}
\hline & Coefficient & $S E$ & Intercept & $\mathrm{R}^{2}$ & $\mathrm{~N}$ \\
\hline Appeal settled & $-9.367 * *$ & 0.311 & $21.156^{* * *}$ & 0.494 & 930 \\
\hline
\end{tabular}

$* * p<0.01$.

${ }^{62}$ Specifically, the model was estimated using the "heckprob" command in Stata (v.10.0). A statistically significant selection parameter, rho $(\rho), p<0.01$, also suggests that use of a Heckman selection model is appropriate.

${ }^{63} \mathrm{An}$ unreported first-stage probit model involves whether an appeal was filed. 
Table 5: Selection Model of Appeal Settlement and the Decision to Appeal

\begin{tabular}{lcc}
\hline & Heckman & s.e. \\
\hline Appeal settled & & \\
ADR participation & $0.300^{*}$ & 0.133 \\
Number of appellants & $-0.080^{*}$ & 0.037 \\
Number of appellees & -0.011 & 0.019 \\
Appeals court w/ADR & 0.008 & 0.205 \\
Trial outcomes & $(\mathrm{ref})$ & \\
Def. won bench trial & $0.464^{* *}$ & 0.158 \\
Plaintiff won bench trial & -0.000 & 0.129 \\
Def. won jury trial & 0.017 & 0.174 \\
Plaintiff won jury trial & & \\
Litigant characteristics & 0.273 & 0.180 \\
Government plaintiff & $0.142^{*}$ & 0.064 \\
Corporate plaintiff & $0.149^{* *}$ & 0.047 \\
Corporate defendant & & \\
(Other variables and the & & \\
$\quad$ decision to appeal equation & & \\
$\quad$ are reported in the Appendix.) & $-0.687^{* *}$ & \\
Rho (Wald test) & 7,962 & \\
$N$ & 925 & \\
Loutcomes & -3146.4 &
\end{tabular}

Notes: Model includes Heckman appeal outcome and decision to appeal equations. Dependent variable in appeal outcome equation is appeal settled; dependent variable in decision to appeal equation is whether an appeal was filed. "Other states" consists of the six states (GA, HI, MA, NC, VA, and WI) that had no more than one appeal reversal. Robust standard errors are in parentheses. The models were estimated using the "heckprob" command in Stata (v.10.0). $* p<0.05 ; * *<0.01$. Full results reported in Table A2.

SourcE: U.S. Dep't of Justice, Bureau of Justice Statistics, Supplemental Survey of Civil Appeals, 2001 (ICPSR 4539).

Other notable findings include the salience of a plaintiff bench trial victory to settlement prospects. Relative to a defendant bench trial victory (the reference group), plaintiffs that prevailed in a bench trial were more likely to settle in response to a defendant appeal. To the extent that the settlement amount was less than the trial court award, this finding implies that either plaintiffs were somewhat nervous about their prospects for prevailing on appeal or that plaintiffs simply valued a settlement over the cost and uncertainty associated with an appeal. Evidence from studies of appeal outcomes provides tentative support for plaintiffs' unease with the stability of favorable bench trial verdicts. ${ }^{64}$

Also, a decrease in the number of appellants corresponds with an increased probability of settlement. The number of appellants (and appellees) was included in the model as a crude proxy for case complexity, at least as it relates to the coordination necessary to generate a settlement. The direction (negative) of the coefficient supports the hypothesized inverse relation between the number of appellants and settlement prospects.

\footnotetext{
${ }^{64}$ Eisenberg \& Heise, supra note 13, at 27, tbl.4.
} 
The principal finding conveyed in Table 5 involving the key independent variable of interest-that ADR participation correlates with an increased likelihood of settlementshould be interpreted with particular caution. Appeals screening efforts were designed to maximize settlements. Specifically, in some jurisdictions, various court personnel exercised judgment about whether to divert an appeal to ADR. One consequence is that the distribution of appeals that participated in ADR programs is presumptively nonrandom. ${ }^{65} \mathrm{~A}$ nonrandom sample limits the generalizability of my findings. Specifically, the nonrandom sample calls into question whether ADR participation's correlation with case settlement is purely a function of ADR programs or, in contrast, simply a reflection of appeals that were selected because they were the type of appeal prone to settlement independent of ADR participation. If case screening efforts were effective, they would have increased the association between ADR participation and settlement. It bears repeating, however, that even though court personnel were supposed to route cases to ADR that were seemingly amenable to settlement, these efforts did not correspond with ADR success (settlement). ${ }^{66}$ Consequently, the degree to which case screening efforts influenced the data is not clear.

Moreover, the comparative ease with which an appeal (including a "strategic" appeal) can be filed also might distort settlement outcomes. A party launching an appeal does not fully internalize costs. Consequently, strategic appeals, those appeals designed merely to delay an eventual outcome or influence and prolong settlement bargaining, will likely increase the number of settled cases. This would occur if the pool of appealed cases includes cases that, on the legal and factual basis, do not objectively warrant an appeal. Such cases would be unusually amenable to a settlement.

\section{Disposition Time}

ADR proponents also tout reduced disposition time as an important virtue of ADR participation. Reduced case disposition time yields numerous benefits, including, on average, reduced litigation costs. Previously discussed descriptive results in Table 4, however, suggested that whether an appeal settled was more influential on disposition time than ADR participation. Findings in Table 6 provide more sophisticated support and identify whether an appeal settled-rather than ADR participation-as the critical explanatory variable in terms of understanding disposition time.

Notably, whether an appeal participated in an ADR program did not influence disposition time. The absence of a statistically significant finding is even more notable given that cases routed toward ADR programs were selected, in part, on the belief that they were especially amenable to settlement. ${ }^{67}$ As Table 6 makes clear, settled cases take far less time on average than cases that do not settle. Thus, the negative finding for the ADR

\footnotetext{
${ }^{65}$ Recall again, however, that Waters and Sweiker found that screeners' efforts did not increase the probability of settlement. See Waters \& Sweiker, supra note 16, at 51, tbl.3.

${ }^{66} \mathrm{Id}$.

${ }^{67}$ See Section II. To be fair, however, it is important to emphasize that other research found that ADR program screeners' efforts did not increase the probability of settlement. See Waters \& Sweiker, supra note 16, at 51, tbl.3.
} 
Table 6: Selection Model of Appeal Disposition Time (Days) and Decision to Appeal

\begin{tabular}{lcc}
\hline & & s.e. \\
\hline Appeal disposition time & & \\
ADR participation & $-9.5694^{* *}$ & 0.422 \\
Appeal settled & -0.046 & 0.474 \\
Number of appellants & 0.026 & 0.107 \\
Number of appellees & 0.683 & 0.015 \\
Appeals court w/ADR & & 0.608 \\
Trial outcomes & $($ ref.) & \\
Def. won bench trial & $1.047^{*}$ & 0.512 \\
Plaintiff won bench trial & 0.748 & 0.472 \\
Def. won jury trial & $1.264^{* *}$ & 0.454 \\
Plaintiff won jury trial & & 1.063 \\
Litigant characteristics & -0.304 & 0.518 \\
Government plaintiff & 0.051 & 0.315 \\
Corporate plaintiff & -0.225 & \\
Corporate defendant & & 0.117 \\
(Other variables and the & & \\
$\quad$ decision to Appeal equation & & \\
$\quad$ are reported in the Appendix.) & $-0.365^{* *}$ & \\
$N$ & 7,950 & \\
$N$ outcomes & 913 & \\
Log likelihood & -5161.7 &
\end{tabular}

Notes: Model includes Heckman appeal disposition time and decision to appeal equations. Dependent variable in disposition time equation is number of days (square root) between appeal filing and disposition. Dependent variable in decision to appeal equation is whether an appeal was filed. "Other states" consists of the three states (GA, MN, and $\mathrm{NC}$ ) where the number of appeals settled was two or fewer. Confidence intervals computed at the 95 percent level. The models were estimated using the "heckman" command in Stata (v.10.0). Robust standard errors reported. $* p<0.05 ; * *<0.01$. Full results reported in Table A3.

Source: U.S. Dep't of Justice, Bureau of Justice Statistics, Supplemental Survey of Civil Appeals, 2001 (ICPSR 4539).

participation variable (i.e., the absence of statistical significance) is even more reliable because its direction runs against any case selection tilt.

Moreover, sample size is not a likely explanation for the absence of a statistically significant influence of ADR participation on appeal disposition time. Even perfectly designed and executed studies may nevertheless fail to uncover socially important differences because the statistical procedures lacked the power to detect the effect flowing from a small sample size.$^{68}$ A power calculation demonstrates that to be 80 percent confident of detecting a statistically significant influence of ADR participation at a 0.05 significance level, requires a sample of at least 471 appeals. ${ }^{69}$ My sample size (913) amply exceeds this requirement.

\footnotetext{
${ }^{68}$ Stanton A. Glantz, Primer of Biostatistics 165 (5th ed. 2002).
}

${ }^{69}$ Power calculation is derived from the "powerreg" command in Stata 10.0 and keys off the independent variable of interest, ADR participation. My sample size (913) also exceeds the required sample size necessary for 90 percent confidence (621). 
Three additional notable findings from Table 6 involve variables that did influence appeal disposition time. First, not surprisingly, cases that settled took far less time than cases that did not settle. ${ }^{70}$ Indeed, whether an appeal settles is easily the single greatest influence on disposition time. This finding, of course, makes perfect sense and, ironically, comports with ADR proponents' claims about the virtues of ADR programs. Although the general claim may be correct - that settled cases take less time than cases that do not settle-these results demonstrate that participating in ADR programs did not correspond with a reduction in disposition time. The implication from the findings in Table 6 is that the relatively enormous influence of settlement on case disposition time overwhelmed the influence of ADR program participation on promoting settlements (Table 5).

A second notable finding involves the party appealing. As Table 6 illustrates, plaintiff victories correlate with increased disposition time. That defendants appeal plaintiff jury trial victories to full appellate court conclusion makes sense given that appellate courts are more likely to disrupt jury trial decisions than bench verdicts ${ }^{71}$ and defendants are far more successful in overturning trial court decisions than are plaintiffs. ${ }^{72}$ Moreover, if defendants are motivated by a general desire to delay judgments for strategic or other reasons, a decision to avoid settlement and pursue an appeal to conclusion would further contribute to increased disposition time.

Third, litigants' characteristics did not influence disposition time. Although defendants appealing adverse plaintiff jury victories correlates with longer disposition times, as a group, corporate defendants were not associated with longer disposition times. This finding runs against the prevailing wisdom that presumably deep-pocketed defendants are inclined to try to "wait out" parties that prevailed at trial by pursuing appeals for purely strategic reasons.

a. Complexities to the Relation Between Settlement and Disposition Time. As discussed above, although ADR participation corresponds with increased settlement rates (Table 5), it does not correlate with a reduction in disposition time (Table 6). Rather, as Table 6 makes clear, settlement is a robust correlate of reduced disposition time. The combination of the findings from Tables 5 and 6 , however, might imply that ADR participation does, in fact, contribute to a reduced disposition time and it does so by inducing appeals to settle prior to disposition.

Although such an interpretation is not implausible, further analyses limit its persuasiveness as they do not provide clear support. First, in an effort to separate the influence of the work on disposition time performed by ADR-induced settlements from the influence of non-ADR-induced settlements on disposition time, the model in Table 6 was modified to include an additional dummy interaction variable designed to capture

\footnotetext{
${ }^{70}$ See also Table 4.

${ }^{71}$ Eisenberg \& Heise, supra note 13, at 18, tbl.4.

${ }^{72}$ Id. at 7 , tbl.1.
} 
Table 7: Regression Models of Appeal Disposition Time (Days), by Settlement Outcome

\begin{tabular}{lcccc}
\hline & A Settled & s.e. & B Nonsettled & s.e. \\
\hline Appeal disposition time & & & & \\
ADR participation & 1.348 & 0.754 & $1.240^{* *}$ & 0.409 \\
Number of appellants & 0.065 & 0.362 & -0.036 & 0.113 \\
Number of appellees & 0.224 & 0.241 & 0.029 & 0.018 \\
Appeals court w/ADR & $5.285^{* *}$ & 1.629 & $-1.925^{*}$ & 0.772 \\
Trial outcomes & & & & \\
Def. won bench trial & $($ ref.) & & -0.008 & 0.727 \\
Plaintiff won bench trial & 1.591 & 1.324 & 1.209 & 0.583 \\
Def. won jury trial & 0.461 & 1.189 & $1.623^{* *}$ & 0.541 \\
Plaintiff won jury trial & 1.136 & 1.349 & & \\
Litigant characteristics & & & 0.769 & 0.825 \\
Government plaintiff & -1.885 & 2.139 & -0.237 & 0.530 \\
Corporate plaintiff & 0.718 & 0.816 & & 0.464 \\
Corporate defendant & -0.185 & 0.583 & & \\
(Other variables are reported & & & 0.243 & 233.86 \\
$\quad$ in the Appendix.) & & 346.08 & 725 & \\
Constant & $765.08^{*}$ & & & \\
$R^{2}$ & 0.226 & & & \\
$N$ & 371 & & & \\
\hline
\end{tabular}

Notes: Dependent variable is number of days (square root) between appeal filing and disposition. "Other states" consists of the three states (GA, MN, and NC) where the number of appeals settled was two or fewer. Confidence intervals computed at the 95 percent level. The models were estimated using the "reg" command in Stata (v.10.0). Robust standard errors reported. $* p<0.05$; $* *<0.01$. Full results reported in Table A4.

Source: U.S. Dep't of Justice, Bureau of Justice Statistics, Supplemental Survey of Civil Appeals, 2001 (ICPSR 4539).

settled appeals that participated in ADR. Results from the supplemental appeal disposition time model comport with the core results in Table 6 . The coefficient for the interactive variable, while positive, did not achieve statistical significance. The key variable explaining reduced disposition time is settled appeals that did not involve ADR participation. ${ }^{73}$

Second, findings from additional regression analyses, presented in Table 7, also support the argument that ADR participation did not correlate with a net decrease in disposition time, independent of the decreases that settlement yielded. The models in Table 7 resemble those in Table 6, except that the subpools of settled (Column A) and nonsettled (Column B) cases are separated. The key variable of interest is ADR participation. For appeals that settled (Column A), ADR participation correlates with an increase in disposition time, though the coefficient does not achieve statistical significance. For appeals

\footnotetext{
${ }^{73}$ In unreported supplemental analyses, the model in Table 6 was rerun to include an interaction dummy variable identifying those appeals that participated in ADR and settled. As the model already includes separate dummy variables for appeals that settled as well as appeals that participated in ADR, the interaction dummy variable isolates the independent influence of appeals that settled in conjunction with ADR participation from the influence of settled appeals that did not involve ADR on disposition time.
} 
that did not settle (Column B), ADR participation corresponds with a significant increase in disposition time.

Finally, in another effort to explore a potentially endogenous relation between ADR participation and appeals disposition time, variants of the core appeal disposition time and appeal settled models ${ }^{74}$ were estimated with a two-stage simultaneous model designed for endogenous variables that are both continuous (disposition time) and dichotomous (ADR participation) ${ }^{75}$ Results from the estimations do not provide support for the endogeneity hypothesis.

To be sure, the precise contours of the relation between ADR participation and appeals disposition time are likely complex and case specific. Moreover, these results do not support the proposition that no relation exists-indeed, some type and form of a relation surely exists. At the same time, however, the results do not support the opposite proposition-that ADR participation contributes to reduced disposition times by inducing appeals to settle prior to disposition. The complexity of the hypothesized relation between ADR participation and disposition time, combined with data limitations, warrants interpretative caution.

Although not conclusive, findings presented in Table 7 complement prior findings and provide additional support for the argument that ADR participation does not correspond with a reduction in disposition time. To be sure, ADR participation obviously performs important work by increasing the probability of settlement. Settled cases typically take less time to complete than cases that resist settlement. What the findings suggest, however, is that time invested in ADR participation does not appear to correlate with reduced disposition time.

One explanation for the findings in Table 7 leverages the practical realities of litigation. ADR participation involves an additional step for litigants. Such an additional step that does not prompt a settlement adds obvious time to disposition, though the amount of time will vary across lawsuits and depend on the particular type of ADR program involved. More interesting is that ADR participation correlates (though not in a statistically significant manner) with increased disposition time even for cases that settled, as compared to settled cases that did not involve ADR. Results presented in Tables 5, 6, and 7 converge on the finding that although ADR participation increases the probability of a settlement, what reduces appeal disposition time is settlement, regardless of whether ADR is involved.

\section{E. Courts' Institutional Interests in Mandating ADR Participation}

If my central empirical claims are correct-that ADR participation achieves one goal (inducing settlement) but not another key goal (reducing disposition time)—why do an increasing number of appellate (and other) courts impose ADR participation? After all, from the perspective of most litigants, ADR efficacy is mixed. Moreover, if it made sense for

\footnotetext{
${ }^{74}$ Variants of the core models (specifically, more parsimonious versions of the core models) were necessary to achieve model convergence.
}

${ }^{75}$ Various models were estimated using the "cdsimeq" and "treatreg" commands in Stata (v.10.0). 
litigants to settle, presumably most would do so. ADR participation is not a prerequisite for settlement.

One explanation for courts' increasing appetite for imposing mandatory ADR participation emerges when one assesses ADR efficacy from the courts'-rather than the litigants'-perspective. Courts have sought policies to reduce caseloads for years. ${ }^{76}$ Courts' institutional interests strongly favor settlement as settled cases reduce judicial docket loads. As Table 5 makes clear, ADR participation corresponds with an increased probability of settlement. As Tables 6 and 7 illustrate, however, ADR participation is not costless. The financial cost associated with ADR participation-such as litigation cost increases incident to increased disposition time-is directly borne by litigants, not courts. Thus, from an institutional perspective, appellate courts have an incentive to impose ADR participation as they can internalize the benefits and externalize most of the associated costs.

\section{Conclusion}

Results from this study indicate that within the appeals context, ADR programs deliver on only some (increased likelihood of settlement)—but not all (reduced disposition time)—of their promises. In some ways, however, these results may reflect more on the particular stage of litigation studied-appellate-and less on ADR's potential efficacy at other litigation stages. To the extent that ADR seeks to achieve its goals principally by increasing information sharing and reducing information asymmetries between combating litigants, the appeals context is far from optimal. Simply put, by the time litigants survive pretrial motions and a trial, much of the salient information about a case is known to the litigants. Consequently, when it comes to reducing appeals disposition time there is simply less work for ADR to perform. With less work available, it is less surprising to learn that ADR participation did not contribute to a reduction in appeals disposition time.

Regardless of what these findings might imply, they contribute to ADR's uneasy reception by litigants. Unease persists even though evidence exists suggesting that ADR participation correlates with increased settlement rates. Litigant ambivalence with ADR is suggested by a relative absence of ex ante agreements among potential litigants to commit to ADR programs should legal disputes arise. Court-mandated ADR programs illustrate how courts' institutional interests can trump litigants' ambivalence. By imposing ADR participation, courts likely seek to internalize ADR's benefits and externalize its costs. Whether courts should continue to mandate ADR participation in an effort to reduce judicial docket loads by increasing settlement rates and imposing on litigants costs associated with increased disposition time persists as a policy question.

\footnotetext{
${ }^{76}$ For data on the increase of case filings in state courts of general jurisdiction over time (between 1976 and 2002), see Marc Galanter, The Vanishing Trial: An Examination of Trials and Related Matters in Federal and State Courts, $1 \mathrm{~J}$. Empirical Legal Stud. 459, 507 (2004), tbl.4. For a discussion of the need to reduce judicial caseloads (with an emphasis on federal courts), see William H. Rehnquist, The 1995 Year End Report on the Federal Judiciary (Admin. Office of the U.S. Courts, Washington, DC), Jan. 1998, at 9-13. For a discussion of federal caseloads, see, e.g., David A. Stras, The Supreme Court's Gatekeepers: The Role of Law Clerks in the Certiorari Process, 85 Tex. L. Rev. 947, 965-67 (2007).
} 
APPENDIX

Table A1: Descriptive Statistics of Variables

\begin{tabular}{|c|c|c|c|c|c|}
\hline Variable & Mean & SD & Min. & Max. & $\mathrm{N}$ \\
\hline ADR participation & 0.172 & 0.378 & 0 & 1 & 965 \\
\hline Appeal disposition time & 342.599 & 221.970 & 0 & 1,085 & 930 \\
\hline Appeal settled & 0.431 & 0.495 & 0 & 1 & 965 \\
\hline Reversed trial court & 0.182 & 0.386 & 0 & 1 & 965 \\
\hline Defendant won bench trial & 0.083 & 0.275 & 0 & 1 & 8,038 \\
\hline Plaintiff won bench trial & 0.150 & 0.357 & 0 & 1 & 8,038 \\
\hline Defendant won jury trial & 0.375 & 0.484 & 0 & 1 & 8,038 \\
\hline Plaintiff won jury trial & 0.392 & 0.488 & 0 & 1 & 8,038 \\
\hline $\mathrm{AZ}$ & 0.050 & 0.218 & 0 & 1 & 8,038 \\
\hline CA & 0.157 & 0.364 & 0 & 1 & 8,038 \\
\hline CT & 0.020 & 0.141 & 0 & 1 & 8,038 \\
\hline FL & 0.072 & 0.258 & 0 & 1 & 8,038 \\
\hline GA & 0.016 & 0.124 & 0 & 1 & 8,038 \\
\hline $\mathrm{HI}$ & 0.003 & 0.055 & 0 & 1 & 8,038 \\
\hline IL & 0.053 & 0.225 & 0 & 1 & 8,038 \\
\hline IN & 0.015 & 0.123 & 0 & 1 & 8,038 \\
\hline $\mathrm{KY}$ & 0.019 & 0.137 & 0 & 1 & 8,038 \\
\hline MA & 0.030 & 0.170 & 0 & 1 & 8,038 \\
\hline MI & 0.048 & 0.214 & 0 & 1 & 8,038 \\
\hline MN & 0.025 & 0.156 & 0 & 1 & 8,038 \\
\hline MO & 0.018 & 0.134 & 0 & 1 & 8,038 \\
\hline $\mathrm{NC}$ & 0.013 & 0.113 & 0 & 1 & 8,038 \\
\hline NJ & 0.077 & 0.266 & 0 & 1 & 8,038 \\
\hline NY & 0.038 & 0.192 & 0 & 1 & 8,038 \\
\hline $\mathrm{OH}$ & 0.050 & 0.219 & 0 & 1 & 8,038 \\
\hline PA & 0.097 & 0.295 & 0 & 1 & 8,038 \\
\hline TX & 0.126 & 0.332 & 0 & 1 & 8,038 \\
\hline VA & 0.031 & 0.172 & 0 & 1 & 8,038 \\
\hline WA & 0.026 & 0.159 & 0 & 1 & 8,038 \\
\hline WI & 0.016 & 0.124 & 0 & 1 & 8,038 \\
\hline Motor vehicle & 0.351 & 0.477 & 0 & 1 & 8,038 \\
\hline Assault, slander, libel & 0.039 & 0.193 & 0 & 1 & 8,038 \\
\hline Product liability & 0.015 & 0.120 & 0 & 1 & 8,038 \\
\hline Dangerous premises & 0.115 & 0.319 & 0 & 1 & 8,038 \\
\hline Medical malpractice & 0.106 & 0.308 & 0 & 1 & 8,038 \\
\hline Prof. malpractice & 0.008 & 0.092 & 0 & 1 & 8,038 \\
\hline Other tort & 0.045 & 0.207 & 0 & 1 & 8,038 \\
\hline Employment contract & 0.035 & 0.184 & 0 & 1 & 8,038 \\
\hline Fraud & 0.053 & 0.225 & 0 & 1 & 8,038 \\
\hline Lease & 0.023 & 0.151 & 0 & 1 & 8,038 \\
\hline Seller plaintiff & 0.096 & 0.295 & 0 & 1 & 8,038 \\
\hline Buyer plaintiff & 0.066 & 0.248 & 0 & 1 & 8,038 \\
\hline Other contract & 0.026 & 0.160 & 0 & 1 & 8,038 \\
\hline Property & 0.022 & 0.146 & 0 & 1 & 8,038 \\
\hline Year case filed & 1998.91 & 1.341 & 1985 & 2001 & 8,038 \\
\hline Government plaintiff & 0.008 & 0.091 & 0 & 1 & 8,028 \\
\hline Corporate plaintiff & 0.156 & 0.363 & 0 & 1 & 8,028 \\
\hline
\end{tabular}


Table A1 Continued

\begin{tabular}{lrrrrr}
\hline Variable & Mean & SD & Min. & Max. & N \\
\hline Corporate defendant & 0.425 & 0.494 & 0 & 1 & 8,001 \\
State appeals rev. rate & 37.084 & 15.248 & 0 & 100 & 8,038 \\
Case type appeals rev. rate & 29.589 & 6.069 & 23.077 & 50 & 8,038 \\
Multicounty state & 0.682 & 0.466 & 0 & 1 & 8,038
\end{tabular}

Source: U.S. Dep't of Justice, Bureau of Justice Statistics, Supplemental Survey of Civil Appeals, 2001 (ICPSR 4539).

Table A2: Selection Model of Appeal Settlement and the Decision to Appeal

\begin{tabular}{|c|c|c|}
\hline & Heckman & s.e. \\
\hline \multicolumn{3}{|l|}{ Appeal settled } \\
\hline ADR participation & $0.300 *$ & 0.133 \\
\hline Number of appellants & $-0.080 *$ & 0.037 \\
\hline Number of appellees & -0.011 & 0.019 \\
\hline Appeals court w/ADR & 0.008 & 0.205 \\
\hline \multicolumn{3}{|l|}{ Trial outcomes } \\
\hline Def. won bench trial & (ref) & \\
\hline Plaintiff won bench trial & $0.464^{* *}$ & 0.158 \\
\hline Def. won jury trial & -0.000 & 0.129 \\
\hline Plaintiff won jury trial & 0.017 & 0.174 \\
\hline \multicolumn{3}{|l|}{ States } \\
\hline $\mathrm{AZ}$ & (ref) & \\
\hline $\mathrm{CA}$ & $-0.729 * *$ & 0.159 \\
\hline CT & - & \\
\hline FL & -0.411 & 0.286 \\
\hline $\mathrm{HI}$ & $-5.972 * *$ & 0.585 \\
\hline IL & $-0.672 *$ & 0.273 \\
\hline IN & -0.112 & 0.241 \\
\hline $\mathrm{KY}$ & $0.249 *$ & 0.112 \\
\hline MA & $0.725^{*}$ & 0.335 \\
\hline MI & 0.258 & 0.251 \\
\hline MO & $-0.349 * *$ & 0.111 \\
\hline NJ & $-0.775^{* *}$ & 0.284 \\
\hline NY & $-1.035^{* *}$ & 0.252 \\
\hline $\mathrm{OH}$ & $-0.869 * *$ & 0.208 \\
\hline PA & $-0.762 * *$ & 0.245 \\
\hline $\mathrm{TX}$ & $-0.529 * *$ & 0.204 \\
\hline VA & - & \\
\hline WA & 0.115 & 0.240 \\
\hline WI & - & \\
\hline Other states & $-0.675^{*}$ & 0.281 \\
\hline Multicounty state & $0.630^{*}$ & 0.260 \\
\hline \multicolumn{3}{|l|}{ Case types } \\
\hline Motor vehicle & (ref) & \\
\hline Dangerous premises & $-0.441 * *$ & 0.115 \\
\hline Product liability & $-0.989 * *$ & 0.173 \\
\hline
\end{tabular}


Table A2 Continued

\begin{tabular}{|c|c|c|}
\hline & Heckman & s.e. \\
\hline Assault, slander, libel & $-0.630 * *$ & 0.201 \\
\hline Medical malpractice & $-0.550 * *$ & 0.134 \\
\hline Prof. malpractice & $-0.999 * *$ & 0.230 \\
\hline Other tort & $-0.918 * *$ & 0.202 \\
\hline Fraud & $-0.652 * *$ & 0.224 \\
\hline Seller plaintiff & $-0.427 *$ & 0.200 \\
\hline Buyer plaintiff & $-0.626 * *$ & 0.175 \\
\hline Employment contract & $-1.014 * *$ & 0.208 \\
\hline Lease & -0.451 & 0.235 \\
\hline Other contract & $-0.518^{*}$ & 0.241 \\
\hline Property & $-1.387 * *$ & 0.263 \\
\hline Year case filed & $0.078^{*}$ & 0.022 \\
\hline \multicolumn{3}{|l|}{ Litigant characteristics } \\
\hline Government plaintiff & -0.245 & 0.408 \\
\hline Corporate plaintiff & -0.147 & 0.218 \\
\hline Corporate defendant & -0.032 & 0.711 \\
\hline Constant & $-154.07 *$ & 67.68 \\
\hline \multicolumn{3}{|l|}{ Decision to appeal } \\
\hline \multicolumn{3}{|l|}{ Trial outcomes } \\
\hline Def. won bench trial & (ref.) & \\
\hline Plaintiff won bench trial & $-0.238^{*}$ & 0.067 \\
\hline Def. won jury trial & -0.093 & 0.105 \\
\hline Plaintiff won jury trial & 0.124 & 0.100 \\
\hline State appeal rev. rate & $-0.015^{*}$ & 0.007 \\
\hline Case type appeal rev. rate & $0.048^{* *}$ & 0.006 \\
\hline Multicounty state & 0.137 & 0.217 \\
\hline \multicolumn{3}{|l|}{ Case types } \\
\hline Motor vehicle & (ref.) & \\
\hline Dangerous premises & $0.304^{* *}$ & 0.112 \\
\hline Product liability & $0.559^{* *}$ & 0.144 \\
\hline Assault, slander, libel & $-0.236^{*}$ & 0.116 \\
\hline Medical malpractice & $0.636^{* *}$ & 0.085 \\
\hline Prof. malpractice & $0.364 *$ & 0.154 \\
\hline Other tort & $0.843^{* *}$ & 0.102 \\
\hline Fraud & $0.467^{* *}$ & 0.121 \\
\hline Seller plaintiff & $0.390^{* *}$ & 0.077 \\
\hline Buyer plaintiff & $0.508^{* *}$ & 0.076 \\
\hline Employment contract & - & - \\
\hline Lease & $0.721^{* *}$ & 0.212 \\
\hline Other contract & 0.017 & 0.112 \\
\hline Property & $0.890 * *$ & 0.184 \\
\hline Year case filed & $-0.057 * *$ & 0.021 \\
\hline \multicolumn{3}{|l|}{ Litigant characteristics } \\
\hline Government plaintiff & 0.273 & 0.180 \\
\hline Corporate plaintiff & $0.142 *$ & 0.064 \\
\hline Corporate defendant & $0.149^{* *}$ & 0.047 \\
\hline Constant & $111.02 *$ & 42.97 \\
\hline Rho (Wald test) & $-0.687 * *$ & 0.162 \\
\hline$N$ & 7,962 & \\
\hline
\end{tabular}


Table A2 Continued

\begin{tabular}{lcc}
\hline & Heckman & s.e. \\
\hline Noutcomes & 925 \\
Log likelihood & -3146.4 & \\
\hline
\end{tabular}

Notes: Model includes Heckman appeal outcome and decision to appeal equations. Dependent variable in appeal outcome equation is appeal settled; dependent variable in decision to appeal equation is whether an appeal was filed. "Other states" consists of the six states (GA, HI, MA, NC, VA, and WI) that had no more than one appeal reversal. Robust standard errors are in parentheses. The models were estimated using the "heckprob" command in Stata (v.10.0). $* p<0.05 ; * * p<0.01$.

SourcE: U.S. Dep't of Justice, Bureau of Justice Statistics, Supplemental Survey of Civil Appeals, 2001 (ICPSR 4539).

Table A3: Selection Model of Appeal Disposition Time (Days) and Decision to Appeal

\begin{tabular}{lcc}
\hline & & s.e. \\
\hline Appeal disposition time & & \\
ADR participation & 0.669 & 0.422 \\
Appeal settled & $-9.514^{* *}$ & 0.474 \\
Number of appellants & -0.046 & 0.107 \\
Number of appellees & 0.026 & 0.015 \\
Appeals court w/ADR & 0.683 & 0.608 \\
Trial outcomes & & \\
Def. won bench trial & $($ ref.) & \\
Plaintiff won bench trial & $1.047^{*}$ & 0.512 \\
Def. won jury trial & 0.748 & 0.472 \\
Plaintiff won jury trial & $1.264^{* *}$ & 0.454 \\
Litigant characteristics & & \\
Government plaintiff & -0.304 & 1.063 \\
Corporate plaintiff & 0.051 & 0.518 \\
Corporate defendant & -0.225 & 0.315 \\
States & & \\
AZ & $($ ref.) & \\
CA & 0.369 & 1.114 \\
CT & - & - \\
FL & -1.571 & 1.178 \\
HI & 1.501 & 1.014 \\
IL & 1.532 & 1.277 \\
IN & $-2.025^{* *}$ & 0.698 \\
KY & $1.407^{* *}$ & 0.283 \\
MA & $6.290^{* *}$ & 1.128 \\
MI & $2.018^{* *}$ & 0.724 \\
MO & $-0.775^{*}$ & 0.316 \\
NJ & -1.343 & 0.984 \\
NY & 0.139 & 0.344 \\
OH & $-4.843^{* *}$ & 1.152 \\
PA & -2.122 & 1.098 \\
TX & -1.292 & 1.052 \\
VA & & -
\end{tabular}

VA 
Table A3 Continued

\begin{tabular}{|c|c|c|}
\hline & & s.e. \\
\hline WA & $3.739 * *$ & 0.739 \\
\hline WI & - & - \\
\hline Other states & -0.602 & 1.506 \\
\hline Multicounty state & $2.084^{*}$ & 1.008 \\
\hline \multicolumn{3}{|l|}{ Case types } \\
\hline Motor vehicle & (ref.) & \\
\hline Dangerous premises & -0.712 & 0.689 \\
\hline Product liability & 0.099 & 0.908 \\
\hline Assault, slander, libel & 1.230 & 0.955 \\
\hline Medical malpractice & -1.099 & 0.770 \\
\hline Prof. malpractice & -1.076 & 1.409 \\
\hline Other tort & 0.585 & 0.881 \\
\hline Fraud & -0.225 & 0.812 \\
\hline Seller plaintiff & -0.290 & 0.751 \\
\hline Buyer plaintiff & -0.824 & 0.744 \\
\hline Employment contract & -0.537 & 0.894 \\
\hline Lease & 0.637 & 1.793 \\
\hline Other contract & -0.870 & 1.029 \\
\hline Property & 0.397 & 1.135 \\
\hline Year case filed & $-0.236^{*}$ & 0.109 \\
\hline Constant & $492.36^{*}$ & 217.97 \\
\hline \multicolumn{3}{|l|}{ Decision to appeal } \\
\hline \multicolumn{3}{|l|}{ Trial outcomes } \\
\hline Def. won bench trial & (ref.) & \\
\hline Plaintiff won bench trial & $-0.241 * *$ & 0.083 \\
\hline Def. won jury trial & -0.094 & 0.089 \\
\hline Plaintiff won jury trial & 0.111 & 0.090 \\
\hline State appeal rev. rate & $-0.016^{* *}$ & 0.003 \\
\hline Case type appeal rev. rate & $0.047 * *$ & 0.006 \\
\hline Multicounty state & 0.133 & 0.104 \\
\hline \multicolumn{3}{|l|}{ Case types } \\
\hline Motor vehicle & (ref.) & \\
\hline Dangerous premises & $0.304^{* *}$ & 0.088 \\
\hline Product liability & $0.544 * *$ & 0.149 \\
\hline Assault, slander, libel & $-0.240 *$ & 0.135 \\
\hline Medical malpractice & $0.625^{* *}$ & 0.079 \\
\hline Prof. malpractice & $0.375^{*}$ & 0.160 \\
\hline Other tort & $0.839 * *$ & 0.081 \\
\hline Fraud & $0.457 * *$ & 0.084 \\
\hline Seller plaintiff & $0.385^{* *}$ & 0.089 \\
\hline Buyer plaintiff & $0.488 * *$ & 0.094 \\
\hline Employment contract & - & - \\
\hline Lease & $0.713^{* *}$ & 0.208 \\
\hline Other contract & -0.013 & 0.118 \\
\hline Property & $0.882 * *$ & 0.192 \\
\hline Year case filed & $-0.053 * *$ & 0.018 \\
\hline \multicolumn{3}{|l|}{ Litigant characteristics } \\
\hline Government plaintiff & 0.276 & 0.218 \\
\hline Corporate plaintiff & 0.141 & 0.088 \\
\hline
\end{tabular}


Table A3 Continued

\begin{tabular}{lcc}
\hline & & s.e. \\
\hline Corporate defendant & $0.145^{* * *}$ & 0.051 \\
Constant & $103.92^{*}$ & 36.61 \\
Rho (Wald test) & $-0.365^{* *}$ & 0.117 \\
$N$ & 7,950 & \\
$N$ outcomes & 913 & \\
Log likelihood & -5161.7 & \\
\hline
\end{tabular}

Notes: Model includes Heckman appeal disposition time and decision to appeal equations. Dependent variable in disposition time equation is number of days (square root) between appeal filing and disposition. Dependent variable in decision to appeal equation is whether an appeal was filed. "Other states" consists of the three states (GA, MN, and NC) where the number of appeals settled was two or fewer. Confidence intervals computed at the 95 percent level. The models were estimated using the "heckman" command in Stata (v.10.0). Robust standard errors reported. $* p<0.05 ; * * p<0.01$.

Source: U.S. Dep't of Justice, Bureau of Justice Statistics, Supplemental Survey of Civil Appeals, 2001 (ICPSR 4539).

Table A4: Regression Models of Appeal Disposition Time (Days), by Settlement Outcome

\begin{tabular}{lcccc}
\hline & A Settled & s.e. & B Nonsettled & s.e. \\
\hline Appeal disposition time & & & & \\
ADR participation & 1.348 & 0.754 & $1.240^{* *}$ & 0.409 \\
Number of appellants & 0.065 & 0.362 & -0.036 & 0.113 \\
Number of appellees & 0.224 & 0.241 & 0.029 & 0.018 \\
Appeals court w/ADR & $5.285^{* *}$ & 1.629 & $-1.925^{*}$ & 0.772 \\
Trial outcomes & & & & \\
Def. won bench trial & $(\mathrm{ref})$. & & $(\mathrm{ref})$. & \\
Plaintiff won bench trial & 1.591 & 1.324 & -0.008 & 0.727 \\
Def. won jury trial & 0.461 & 1.189 & 1.209 & 0.583 \\
Plaintiff won jury trial & 1.136 & 1.349 & $1.623^{* *}$ & 0.541 \\
Litigant characteristics & & & & \\
Government plaintiff & -1.885 & 2.139 & 1.769 & 0.825 \\
Corporate plaintiff & 0.718 & 0.816 & 0.053 & 0.530 \\
Corporate defendant & -0.185 & 0.583 & -0.237 & 0.464 \\
States & & & & \\
AZ & $(\mathrm{ref})$. & & $(\mathrm{ref})$. & \\
CA & $-7.499^{* *}$ & 1.524 & -1.140 & 1.080 \\
CT & $-8.716^{* *}$ & 1.962 & - & - \\
FL & $-3.467^{* *}$ & 0.732 & $-7.771^{* *}$ & 1.341 \\
HI & - & - & 2.285 & 1.258 \\
IL & - & - & $-4.545^{* *}$ & 1.390 \\
IN & $5.234^{* *}$ & 1.872 & $-5.453^{* *}$ & 0.811 \\
KY & -0.876 & 0.712 & $2.569^{* *}$ & 0.298 \\
MA & -1.454 & 2.411 & $3.552^{* *}$ & 0.887 \\
MI & $-2.629 * *$ & 0.928 & $5.150^{* *}$ & 0.421 \\
MO & -1.444 & 0.812 & -0.377 & 0.299 \\
NJ & $-10.836^{* *}$ & 2.203 & $-3.019^{* *}$ & 0.995 \\
NY & $3.916^{* *}$ & 0.965 & $1.691^{* *}$ & 0.277 \\
& & & &
\end{tabular}


Table A4 Continued

\begin{tabular}{|c|c|c|c|c|}
\hline & A Settled & s.e. & $B$ Nonsettled & s.e. \\
\hline $\mathrm{OH}$ & $-12.923 * *$ & 1.824 & $-6.192 * *$ & 1.381 \\
\hline PA & $-4.791 * *$ & 0.802 & $-6.650^{* *}$ & 1.179 \\
\hline $\mathrm{TX}$ & $-9.863^{* *}$ & 1.976 & $-2.680 * *$ & 0.928 \\
\hline VA & - & - & - & - \\
\hline WA & $4.390^{*}$ & 1.824 & $3.144 * *$ & 0.758 \\
\hline WI & - & - & - & - \\
\hline Other states & $6.705^{*}$ & 2.467 & -2.592 & 2.073 \\
\hline Multicounty state & $7.891 * *$ & 1.882 & $5.215^{* *}$ & 0.809 \\
\hline \multicolumn{5}{|l|}{ Case types } \\
\hline Motor vehicle & (ref.) & & (ref.) & \\
\hline Dangerous premises & 0.365 & 0.793 & $1.281 *$ & 0.625 \\
\hline Product liability & 1.242 & 1.820 & 2.556 & 1.289 \\
\hline Assault, slander, libel & $2.257 *$ & 1.183 & $2.874^{*}$ & 1.131 \\
\hline Medical malpractice & -0.303 & 0.925 & 1.392 & 0.912 \\
\hline Prof. malpractice & -0.439 & 2.821 & $2.754^{*}$ & 1.070 \\
\hline Other tort & $2.849^{*}$ & 1.247 & $1.753^{*}$ & 0.808 \\
\hline Fraud & 1.251 & 1.219 & $1.825^{*}$ & 0.875 \\
\hline Seller plaintiff & 0.914 & 1.004 & 0.873 & 1.253 \\
\hline Buyer plaintiff & -0.058 & 0.973 & 1.577 & 0.832 \\
\hline Employment contract & 1.539 & 0.919 & 1.628 & 0.805 \\
\hline Lease & 1.416 & 2.433 & 2.856 & 1.675 \\
\hline Other contract & 0.424 & 1.091 & 0.515 & 1.633 \\
\hline Property & 6.191 & 3.497 & $1.791^{*}$ & 0.874 \\
\hline Year case filed & $-0.380 *$ & 0.173 & $-0.238^{*}$ & 0.117 \\
\hline Constant & $765.08^{*}$ & 346.08 & $492.29 *$ & 233.86 \\
\hline$R^{2}$ & 0.226 & & 0.243 & \\
\hline$N$ & 371 & & 725 & \\
\hline
\end{tabular}

Notes: Dependent variable is number of days (square root) between appeal filing and disposition. "Other states" consists of the three states (GA, MN, and NC) where the number of appeals settled was two or fewer. Confidence intervals computed at the 95 percent level. The models were estimated using the "reg" command in Stata (v.10.0). Robust standard errors reported. $* p<0.05 ; * p<0.01$.

Source: U.S. Dep't of Justice, Bureau of Justice Statistics, Supplemental Survey of Civil Appeals, 2001 (ICPSR 4539). 